\title{
The Influence of Trust in Traditional Contracting: Investigating the "Lived Experience" of Stakeholders
}

\author{
Scott Strahorn, Thayaparan Gajendran and Graham Brewer \\ School of Architecture and Built Environment, University of Newcastle, Australia
}

\begin{abstract}
The traditional procurement approach is ever-present within the construction industry. With fundamental design principles founded on definitive risk allocation, this transactional based approach fails to acknowledge or foster the cooperative relationships considered to be vital to the success of any project. Contractual design encourages stakeholders to defend their own individual interest to the likely detriment of project objectives. These failings are not disputed, however, given that trust is a fundamental requirement for human interaction the influence of trust is potentially important in terms of stakeholder relationships and ultimate project success. Trust is therefore examined within this context. A conceptual framework of trust is presented and subsequently used to code and analyse detailed, semi-structured interviews with multiple stakeholders from different projects. Using a phenomenological investigation of trust via the lived experiences of multiple practitioners, issues pertaining to the formation and maintenance of trust within traditionally procured construction projects are examined. Trust was found to be integral to the lived experiences of practitioners, with both good and bad relationships evident within the constructs of traditional procurement mechanisms. In this regard, individual personalities were considered significant, along with appropriate risk identification and management. Communication, particularly of an informal nature, was also highlighted. A greater emphasis on project team selection during the initial stages of a project would therefore be beneficial, as would careful consideration of the allocation of risk. Contract design would also be enhanced through prescriptive protocols for developing and maintaining trust, along with mandated mechanisms for informal communication, particularly when responding to negative events. A greater understanding regarding the consequences of lost trust and the intricacies of trust repair would also be of value.
\end{abstract}

Keywords: Traditional project procurement, trust, trust repair, relationships

Paper Type: Research article

\section{Introduction}

The construction industry environment is inherently challenging, wherein the management and appropriate allocation of risk, and the ability to deal with states of rapid change are critical skills (Sakal, 2005). The traditional procurement approach regularly adopted across the industry embodies transactional-based precepts and is consequently constrained by them (Forgues and Koskela, 2009; Ibrahim, Costello and Wilkinson, 2011), particularly when dealing with complex and high risk endeavours(Campbell, 2004).

\footnotetext{
Copyright: Construction Economics and Building 2015. (C) 2015 Scott Strahorn, Thayaparan Gajendran and Graham Brewer. This is an Open Access article distributed under the terms of the Creative Commons Attribution 4.0 Unported (CC BY 4.0) License (https://creativecommons.org/licenses/by/4.0/), allowing third parties to copy and redistribute the material in any medium or format and to remix, transform, and build upon the material for any purpose, even commercially, provided the original work is properly cited and states its license.
}

Citation: Strahorn, S., Gajendren, T. and Brewer, G., 2015. The influence of trust in traditional contracting: investigating the "lived experience" of stakeholders, Construction Economics and Building, 15(2), 81-101. DOI:

http://dx.doi.org/10.5130/AJCEB.v15i2.4408

Corresponding author: Scott Strahorn; Email - scott@strahornconstructiongroup.com.au 
Traditional procurement mechanisms are intended to definitively allocate risk amongst stakeholders despite the fact that, at the project outset, it is fundamentally impossible to accurately predict all of its risks and uncertainties (Macneil, 1978). Moreover, in focussing on potential uncertainties they fail to recognise or facilitate the cooperative relationships that are considered critical to the success of a contractual arrangement, particularly in terms of dealing with the unforeseeable (McInnis, 2003).

Similarly, the principles underpinning traditional procurement mechanisms ensure that the respective parties act in a manner which defends their own individual interests, often leading to disputes and outcomes not consistent with what is best for the project as a whole (Chan et al., 2006). Adversarial relationships characterised by conflict are thus triggered (Chen and Chen, 2007) by the competitive, fixed price environment of the traditional contract (Pesämaa, Eriksson and Hair, 2009). From project inception onwards, onerous contract conditions potentially discourage responsible tendering, attracting opportunistic parties to enter into an agreement with devious intentions. These are based on unrealistic tender pricing in anticipation of variations (Rahman and Kumaraswamy, 2004), and exploitation of weaknesses in the contract documentation (Mosey, 2003).

Ultimately traditional procurement mechanisms have been found to negatively impact on project outcomes in terms of disputes (Pesämaa, Eriksson and Hair, 2009), distrust, mistrust and conflict (Sakal, 2005), loss of productivity ( $\mathrm{Ng}$ et al., 2002), high levels of litigation (Yiu and Cheung, 2007), a prevalence for disagreement rather than cooperation (Wood and McDermott, 1999), cost blow outs and project delays (Chan, Chan and Ho, 2003). The failings of traditional procurement mechanisms and the need for alternatives have therefore been broadly acknowledged by literature (Chen and Chen, 2007).

In light of these acknowledged deficiencies, the influence of trust has the potential to be significant in terms of stakeholder relationships and overall project success (Pinto, Slevin and English, 2008). Trust is considered to be a fundamental requirement for human interaction (Romahn and Hartman, 1999), and there is widespread agreement on the value of trust in human behaviour (Bigley and Pearce, 1998). Similarly, trust is deemed vital to facilitating cooperative processes within the project environment (Kramer, 1999; Wicks, Berman and Jones, 1999). Hence, by way of improving relationships and maintaining healthy partnerships, the importance of trust within a transactional procurement context is logically significant (Pinto, Slevin and English, 2008). This research therefore investigates trust within this context. To this end, the influence of trust within other procurement mechanisms is acknowledged (She, 2013; Strahorn, Thayaparan and Brewer, 2013; Yeung, Chan and Chan, 2007), however, an investigation of trust other than within traditional procurement mechanisms is intentionally not within the scope of this paper.

For the purpose of this study, the definition of trust provided by Rosseau, Sitkin, Burt and Camerer (1998, p.395) has been adopted. "Trust is a psychological state comprising the intention to accept vulnerability based upon positive expectations of the intentions or behaviour of another". Within the context of this research, trust has not been considered as behaviour but rather as a psychological state experienced by practitioners. Furthermore, trust has been distinguished from cooperative relationships, which can be present even without trust; mere compliance as an observed behaviour has therefore not been taken to imply the existence of trust (Brewer and Strahorn, 2012).

Building upon these precepts, this research adopts a phenomenological lens to explore the formation and maintenance of trust through the lived experiences of multiple practitioners within construction projects procured utilising traditional procurement mechanisms, e.g. lump sum, construct only, and design and construct contracts. A theoretical framework of trust is presented that drove the design and conduct of detailed, semi-structured interviews, facilitating 
their subsequent coding and analysis. This reveals the importance of communication, particularly of an informal nature, as well as appropriate risk identification and management, and individual stakeholder personalities to the success of traditionally procured projects. Limitations regarding the appropriateness of the traditional procurement approach are also exposed. By way of enlightening the influence of trust within the context of a traditional procurement environment, potential improvements in the design and implementation of future traditional procurement mechanisms have been highlighted. A greater understanding of trust on the part of project participants is also likely to influence individual attitudes and behaviours, with enhanced project outcomes the result.

\section{Literature Review}

When considering past research, contextual specifics have provided the impetus for the development of varied definitions and models of trust. Debate and ambiguity have resulted (Hartman, 1999) with the subjective nature of trust proving to be the limiting factor in terms of developing a universally applicable trust model (Becerra, Denzinger and Kremer, 2001). In order to ensure appropriateness for use in a project environment, this research has focused substantially on the discipline of management, with a thematic review of existing trust models and literature resulting in a comprehensive framework of trust themes (Brewer and Strahorn, 2012): this is summarised in figure 1 and expanded upon thereafter.
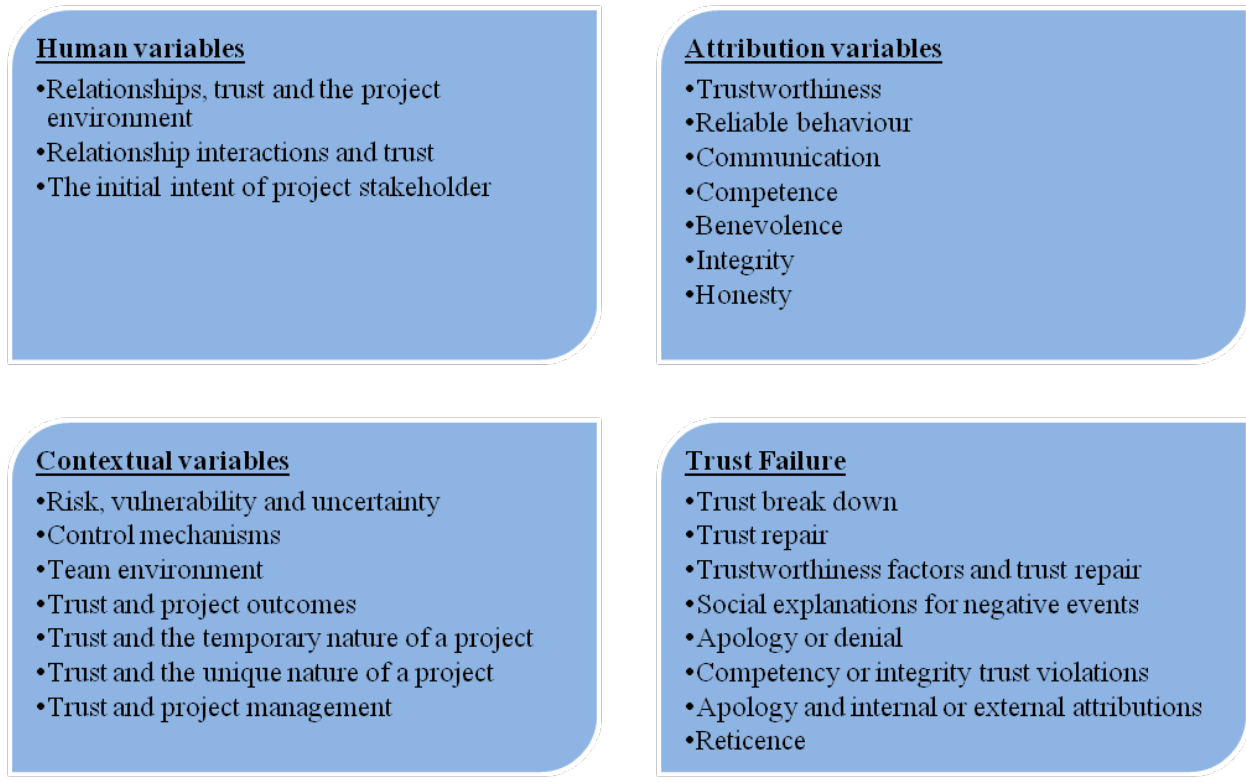

Figure 1: Thematic Trust Framework (main theme codes) Source(s): Adapted from (Brewer and Strahorn, 2012)

\section{Human Variables}

Literature is eloquent regarding the human dimension to trust, with the nature of relationships central in this regard. A relationship can be expressed as the condition in which objectives are achieved via a dependence on another party (Sheppard and Sherman, 1998). The development of trust cannot eventuate without the existence of a relationship (Rosseau et al., 1998); similarly cooperative relationships cannot exist without trust (Misztal, 1996). Relationships have a temporal dimension (Karlsen, Græe and Massaoud, 2008), and the ongoing interactions which underpin a relationship are a fundamental determinant of trust (Tomlinson and Mayer, 2009). The correlation between project success and trusting stakeholder relationships is also strong 
(Pinto, Slevin and English, 2008), however the full benefits of a trusting relationship cannot be realised unless the trust between the parties is mutual (Romahn and Hartman, 1999).

In terms of relational interactions, positive or negative experiences underpin the casual attributions which individuals form towards one another: such ascriptions arise out of perceived causality, controllability and stability (Weiner, 1986), which consequently dictate future expectations and emotional responses (Tomlinson and Mayer, 2009). Ultimately trust levels between parties are re-assessed and decisions regarding the propensity for future risk taking are made accordingly (Mayer, Davis and Schoorman, 1995).

The initial intent and expectations of project stakeholders are significant in terms of ultimate project success (Munns, 1995). While a pre-emptive demonstration of trustworthy behavior at the commencement of any exchange relationship comes with some risk, the full benefits of trust are likely to be forfeited if an alternate display of non-trusting intent is evident (Whitener et al., 1998). An initial non-trusting intent will ultimately be detrimental to project success (Munns, 1995).

Trust provides the foundation for human interaction (Romahn and Hartman, 1999). An understanding of the function and operation of trust is therefore important in terms of stakeholder relationships and interactions within traditionally procured projects, where recourse to contractual remedies are inevitably regarded as non-trusting actions.

\section{Attribution Variables}

Within a project environment the attribution by someone of some quality or characteristic to another person within the project team is a key behaviour. In order to be deemed trustworthy, one party must display a willingness to act in the best interests of another party (McLain and Hackman, 1995); to this end an individual's characteristics and actions determine the extent to which they are more or less trusted (Good, 1988). Trust building mechanisms that are considered to be important and mutually related to a high degree (Lander et al., 2004)) include communication, reliable behaviour, (Karlsen, Græe and Massaoud, 2008), benevolence, competence, integrity and honesty (McKnight and Chervany, 1995). Attribution variables are therefore significant in terms of trust and its influence (Brewer and Strahorn, 2012).

\section{Contextual Variables}

Uncertainty and risk are unavoidable in any project environment (Schwalbe, 2004), and it is trust in all its forms that ultimately aids the resolution of issues in this regard. Trust (and the subsequent benefits of trust) cannot eventuate without one party accepting some amount of risk (Chow, Cheung and Chan, 2012): within a project context the presence of trust reinforces an individual's motivation towards achieving the overall objectives of a project (Wong et al., 2007).

The provision of control mechanisms that both manage risk and minimise stakeholder vulnerability facilitates the development of trust in the project context (Wong et al., 2007). Conversely, excessive control can have a negative influence on the development of trust, and potentially result in distrust among project partners (Pinto, Slevin and English, 2008). Given that the enactment of any control mechanism results in additional project cost, the presence of trust has the potential to reduce the requirement for control. In this way the nurturing of stakeholder relationships allows individuals to interact without the concern of being exploited (Aubert and Kelsey, 2000). Trust is also considered to be critical in terms of maintaining a positive team environment (Delisle, 2004); equally, a healthy team environment will have a positive influence on the development and subsequent maintenance of trust. This is crucial for assisting cooperative processes (Kramer, 1999), and these improved relationships increase the likelihood of positive project outcomes for all stakeholders (Pinto, Slevin and English, 2008). 
A project by definition is fundamentally a temporary endeavour (PMI, 2008), with this characteristic of significant consequence in terms of building trusting relationships. To this end, the time available to develop trust is limited to the timeframe in which the project must be completed (Hartman, 2002), and as a result, the opportunity to develop long-term trust in interpersonal relationships is hindered (Munns, 1995). The establishment of trust is most often realised over a period of time which includes multiple interactions (Dervitsiotis, 2003). Within the context of a project environment and the development of stakeholder relationships, the importance of trust is therefore subsequently increased (Atkinson, Crawford and Ward, 2006). Conversely however, while the temporary nature of a project may not be absolutely conducive to the development of trusting relationships (Munns, 1995), provided there is no evidence to the contrary, trust during the initial stages of a relationship can actually be bolstered by a natural assumption to trust (McKnight, Cummings and Chervany, 1998). Furthermore, individuals can display high levels of trust even in relationships without any prior history (Meyerson, Weick and Kramer, 1996).

\section{Trust Failure}

Whilst the benefits of trust creation and maintenance are logically apparent, the realities of project environments mean that the breakdown of trusting relationships frequently occurs. The need to understand the processes involved in repairing this damage is therefore important. Negative events in any project directly influence stakeholder relationships, and the subsequent break down in trust can have significant consequences (Lewicki and Bunker, 1996), resulting in reduced trust and the need for trust repair (Kim et al., 2004). The underlying trigger for a negative event will affect the perceptions of trust differently for those involved in it (Lewicki and Bunker, 1996), according to internal, controllable or stable characteristics afforded to the trustee (Tomlinson and Mayer, 2009). Of these, stability is deemed to be the most influential (Weiner, 2001). This is because occurrences that are believed to typify context-specific behaviour facilitate the perception that, under similar circumstances, the same results can be expected in the future (Sitkin and Roth, 1993).

When considering the repair of lost trust - notwithstanding a mistrusted party's attempts to exhibit trustworthiness - low levels of trust will be compounded by the truster's memories of the earlier trust violation (Slovic, 1993). The trust repair process is therefore more complex than initial trust development, since trust repair efforts must not only restore positive expectations in a relationship, but also overcome negative expectations (Kim et al., 2004). Any trust repair effort is therefore likely to require greater effort than was initially required to establish a trusting relationship (Kim et al., 2006).

\section{Methodology}

This study was predicated on the notion that the perception of trust by trusters and trustees is a phenomenon that can be revealed by the purposeful, detailed interrogation of their lived experiences. Moreover, given the absence of a project-specific theory of trust, the adoption of a 'constructivist' perspective (Cresswell and Plano Clark, 2007) was deemed appropriate to examine the diverse perceptions and experiences of construction practitioners in order to develop a theoretical contribution. Driven by these methodological precepts, a phenomenological research method was conceived, utilising the 'emic' perspective (Pike, 1967) necessary in order to capture lived experience; an interview based study was clearly indicated. With regards to trust and its influence, the phenomenological approach has accurately conceptualised the meaningful world that exists via experience. To this end, the significance of lived situations have been examined, and the experience of trust has been described (Wertz et al., 2011). 
A total of 26 interviews provided the data for this study, with details regarding the respective interviewees and subsequent coding identification included in Table 1. Six individual stakeholders from different sectors and multiple projects were interviewed. A further twenty stakeholders were interviewed from three separate projects. Selection and recruitment of the research participants was determined by pragmatism. To this end, all participants were accessibly located, suitably experienced (5+ years of responsibility in their respective role) and had experience in the delivery of major projects procured under traditional procurement mechanisms. Each interview was carried out at a location selected by the participant and was approximately one hour in length. The questions firstly set out to clarify the roles of the respective interviewees, and then examined their attitudes to stakeholder relationships, culture and leadership in general. Questions were then focused more specifically within the context of traditional procurement mechanisms. Accordingly, the data collected via the semi-structured, indepth interviews was recorded and professionally transcribed.

Table 1: Interviewee details

\begin{tabular}{|c|c|c|c|}
\hline Coding Identifier & Designation & Nature of Organisation & Stakeholder \\
\hline $\begin{array}{l}\text { Consultant \# 1: Project } \\
\text { Manager }\end{array}$ & Project Manager & $\begin{array}{l}\text { A large Engineering Consultancy/ Project Management } \\
\text { Organisation }\end{array}$ & Project Management \\
\hline $\begin{array}{l}\text { Contractor \# 1: Project } \\
\text { Manager }\end{array}$ & Project Manager & Small Regional Building Construction Organisation & Contractor \\
\hline $\begin{array}{l}\text { Client \# 1: Contracts } \\
\text { Manager }\end{array}$ & Contracts Manager & Government Infrastructure Construction PM unit & Client \\
\hline $\begin{array}{l}\text { Contractor \# 2: Project } \\
\text { Engineer }\end{array}$ & Project Engineer & $\begin{array}{l}\text { Client Representative in a Major Rail Infrastructure } \\
\text { Construction Coal Supply }\end{array}$ & Contractor \\
\hline $\begin{array}{l}\text { Client \# 2: Senior Project } \\
\text { Manager }\end{array}$ & $\begin{array}{l}\text { Senior Project } \\
\text { Manager }\end{array}$ & Government Infrastructure Construction PM unit & $\begin{array}{l}\text { Client / Project } \\
\text { Management }\end{array}$ \\
\hline $\begin{array}{l}\text { Client \# 3: Senior Project } \\
\text { Manager }\end{array}$ & $\begin{array}{l}\text { Senior Project } \\
\text { Manager }\end{array}$ & Government Infrastructure Construction PM unit & $\begin{array}{l}\text { Client / Project } \\
\text { Management }\end{array}$ \\
\hline $\begin{array}{l}\text { Contractor \#3- Project } \\
\text { Manager }\end{array}$ & Project Manager & Contractor for Warehouse Distribution Project & Contractor \\
\hline Client \#4- Project Manager & Director & Client for Warehouse Distribution Project & Client \\
\hline $\begin{array}{l}\text { Consultant \#2- Project } \\
\text { Manager }\end{array}$ & Project Manager & Project Manager for Warehouse Distribution Project & Project Management \\
\hline Consultant \#3- Architect & Architect & Architect for Warehouse Distribution Project & Architectural Consultant \\
\hline Consultant \#4- Engineer & Senior Engineer & Engineer for Warehouse Distribution Project & Engineering Consultant \\
\hline $\begin{array}{l}\text { Consultant \#5- Quantity } \\
\text { Surveyor }\end{array}$ & Quantity Surveyor & Quantity Surveyor for Warehouse Distribution Project & $\begin{array}{l}\text { Quantity Surveyor } \\
\text { Consultant }\end{array}$ \\
\hline $\begin{array}{l}\text { Subcontractor \#1- Electrical } \\
\text { Services }\end{array}$ & Project Manager & Subcontractor for Warehouse Distribution Project & Subcontractor \\
\hline $\begin{array}{l}\text { Contractor \#4- Project } \\
\text { Manager }\end{array}$ & Project Manager & $\begin{array}{l}\text { Contractor for Hospital Extension- Public Health } \\
\text { Organisation }\end{array}$ & Contractor \\
\hline Consultant \#6- Architect & Architect & $\begin{array}{l}\text { Architect for Hospital Extension- Public Health } \\
\text { Organisation }\end{array}$ & Architectural Consultant \\
\hline Consultant \#7- Engineer & Senior Engineer & $\begin{array}{l}\text { Engineer for Hospital Extension- Public Health } \\
\text { Organisation }\end{array}$ & Engineering Consultant \\
\hline $\begin{array}{l}\text { Consultant \#8- Quantity } \\
\text { Surveyor }\end{array}$ & Quantity Surveyor & $\begin{array}{l}\text { Quantity Surveyor for Hospital Extension- Public Health } \\
\text { Organisation }\end{array}$ & $\begin{array}{l}\text { Quantity Surveyor } \\
\text { Consultant }\end{array}$ \\
\hline $\begin{array}{l}\text { Subcontractor \#2- Internal } \\
\text { partitions and linings }\end{array}$ & Project Manager & $\begin{array}{l}\text { Subcontractor for Hospital Extension- Public Health } \\
\text { Organisation }\end{array}$ & Subcontractor \\
\hline Client \#5- Project Manager & Project Manager & $\begin{array}{lllll}\text { Client for Hospital Extension- } & \text { Public } & \text { Health } \\
\text { Organisation } & & & \\
\end{array}$ & Client \\
\hline $\begin{array}{l}\text { Consultant \#9- Project } \\
\text { Manager }\end{array}$ & Project Manager & $\begin{array}{l}\text { Project Manager for Hospital Extension- Public Health } \\
\text { Organisation }\end{array}$ & Project Management \\
\hline $\begin{array}{l}\text { Contractor \#5- Project } \\
\text { Manager }\end{array}$ & Project Manager & $\begin{array}{l}\text { Contractor for Car park extension to accommodate } \\
\text { office/educational facilities for an educational institution }\end{array}$ & Contractor \\
\hline $\begin{array}{l}\text { Consultant \#10- Client } \\
\text { Representative }\end{array}$ & Project Manager & $\begin{array}{l}\text { Client for Car park extension to accommodate } \\
\text { office/educational facilities for an educational institution }\end{array}$ & Client \\
\hline $\begin{array}{l}\text { Consultant \#11- Project } \\
\text { Manager/Quantity Surveyor }\end{array}$ & $\begin{array}{l}\text { Quantity Surveyor / } \\
\text { Project Manager }\end{array}$ & $\begin{array}{l}\text { Quantity Surveyor and Project Manager for Car park } \\
\text { extension to accommodate office/educational facilities } \\
\text { for an educational institution }\end{array}$ & $\begin{array}{l}\text { Quantity Surveyor } \\
\text { Consultant / Project } \\
\text { Management } \\
\end{array}$ \\
\hline Consultant \#12- Architect & Architect & $\begin{array}{l}\text { Architect for Car park extension to accommodate } \\
\text { office/educational facilities for an educational institution }\end{array}$ & Architectural Consultant \\
\hline Consultant \#13- Engineer & Senior Engineer & $\begin{array}{l}\text { Engineer for Car park extension to accommodate } \\
\text { office/educational facilities for an educational institution }\end{array}$ & Engineering Consultant \\
\hline $\begin{array}{l}\text { Subcontractor \#3- Elevator } \\
\text { Services }\end{array}$ & Project Manager & $\begin{array}{l}\text { Subcontractor for Car park extension to accommodate } \\
\text { office/educational facilities for an educational institution }\end{array}$ & Subcontractor \\
\hline
\end{tabular}


The interview data was subsequently subjected to a thematic analysis process, framed against the developed trust framework (Figure 1), made up of 25 open codes, and 74 axial codes (Brewer and Strahorn, 2012). In broad terms, the data was approached so that the first analytical pass sorted it according to question, and then utilised open coding to reveal predominant trust themes independently of the questions' subject. Thereafter, each of these themes was investigated during second and third analysis rounds utilising axial coding techniques in order to provide detail (where appropriate) to the open code themes. That is, axial codes forthcoming from the developed trust framework were used to guide the subsequent analysis and discussion of pertinent trust themes. The deconstructed, thematically arranged analysis was then subjected to a process of synthesis whereby recurrent themes from across the different interviews were constructed and explained, by confirmatory reference to existing theory wherever possible, and signalling potential theoretical contributions where this was not possible.

\section{Results}

In striving for the development of new theory the evaluation of emerging ideas relative to existing literature is considered to be important (Eisenhardt, 1989). Analysing the interview transcripts with reference to the developed framework of trust themes (Figure 1) facilitated the identification of trust-related issues from real world perspectives, while concurrently highlighting agreement or disagreement with the existing literature. In this regard, Table 2 in Appendix 1 provides a condensed summary of the interviewee quotations central to these results, and as applicable to the experiences of the research participants in terms of trust and its influence.

\section{Human Variables}

\section{Relationships, trust and the project environment}

The value of positive stakeholder relationships was commonly mentioned, and its link to eventual project success was widely accepted (Pinto, Slevin and English, 2008). The presence of open and honest communication, collaboration, cooperation, diplomacy, and positive interactions in general, were all considered conducive to a positive project team environment and of consequent benefit to project performance. On the other hand, when a project participant displayed negative traits such as exploitative behaviour, overly overbearing use of project control mechanisms, unreciprocated trust, unreliability, and an unwillingness to accept responsibility, project outcomes were almost inevitably impacted in a negative way.

The nature of stakeholder relationships was widely described as being contingent upon various influences, including control mechanisms, fulfilment of contractual obligations, allocation and consequent management of risk, and levels of stakeholder profitability. Nevertheless, individual personalities were ultimately felt to be the single most important influence upon project outcomes since they had the power to shape - both positively and negatively - the development of project team culture. The values they brought to the project were moulded by their prior experiences, which largely dictated their initial intent. This could be further modified over time through their interactions with others in the project team, and occasionally by their expectation of building a strategic relationship that would endure beyond the current project.

Traditional procurement mechanisms were not of themselves regarded as an impediment to good stakeholder relationships, and when adverse events did occur it was widely recognised that the existence of good relationships were central to achieving positive resolutions. Moreover, the existence of strong relationships was widely believed to provide a disincentive for exploitative behaviour and to overcome the inclination to resort to adversarial problem-solving. 
In light of the foregoing, it was perhaps surprising how few interviewees were able to point to proactive measures to develop relationships and trust. Whilst most espoused the value of trust and relationships in achieving project goals (Misztal, 1996), few could explain how to set about ensuring that this would occur. Two clues as to why this might be the case emerged: firstly, the ongoing and frequent need to develop new relationships on a project by project basis, and; secondly, the essentially informal nature of relationship building (its dependence upon compatible personalities). As trusting relationships foster project success (Pinto, Slevin and English, 2008), and cooperative relationships are facilitated through trust (Misztal, 1996), a greater emphasis on the need to actively pursue the development of relationships and trust between contracting parties within a traditional procurement context would be advantageous.

\section{Relationship interactions and trust}

In terms of developing and maintaining trusting relationships, most interviewees linked future intentions to past experiences. The preexistence of a trusting relationship with a trading partner was most likely to result in an ongoing trusting relationship in the current project. Conversely the adage "once bitten, twice shy" was invoked by a number of interviewees, frequently expressing risk averse sentiments about their propensity to accept risk or engage in informal trust building behaviours into the future. At times the causes for reticence could be traced back to previous bad experiences where an untried and unknown project participant had failed to perform adequately; clients in particular were unwilling to repeat such actions, perhaps as a consequence of their past experiences.

Ongoing re-evaluation of trust levels in relationships was a continual theme across the interviews, with wariness and vigilance being frequently mentioned, perhaps as a consequence of the increased risk that trusting behaviour placed upon project participants. On the other hand, the risk-reward proposition was also clearly on display, with the hope that actions based upon good faith in the current project might result in favourable consideration for future projects. These actions would include benevolence, integrity and honesty, over and above the normal expectations of competence and reliability. Professionalism was also mentioned, though it was unclear as to whether only professionals would display this range of positive behaviours, or whether the term professionalism was used as shorthand for describing those behaviours.

Long-term, trust-based relationships were identified as beneficial when dealing with major conflicts. A history of successful collaborative working was cited as a significant contributor to overcoming problems - usually through informal measures - that might otherwise have resulted in litigation. This was usually couched in terms of "relationship management".

\section{The initial intent of project stakeholders}

The set of underlying assumptions, attitudes and consequent behaviours that a particular project participant - and more importantly, that participant's representative - brought to the initial project meetings were seen as fundamental to the formation of the project team culture (Munns, 1995). Different interviewees expressed contrasting positions during the early stages of project establishment, ranging from the strictly contractual through to the deeply collaborative. Interestingly, this was also reported as a generational issue, with younger interviewees espousing more collaborative intentions, and contrasting these with the intransigent "us versus them" mentality of their seniors.

Opinions differed as to the beneficial and detrimental impact of aggressive behaviour during the early stages of the project. Many participants felt that this approach would have a negative impact upon the conduct of the project, though a few of them reported a softening of stance into cooperation and collaboration once that project team had been initiated. Where negative 
influences originated from major clients, those charged with the management of the project often had to work hard to modify the project team culture into something more cooperative. Blatant exploitation however, was universally regarded to be a negative influence on project outcomes. As the outcomes of any project are influenced by the initial intent and expectations of the parties involved (Munns, 1995), a greater level of awareness amongst project practitioners in this regard would be valuable. Similarly, as a non-trusting intent will be detrimental to project success (Munns, 1995), an improved understanding regarding the influence of trust and its dimensions would likely help overcome the negative effects of preconceived attitudes and an adversarial culture. While a pre-emptive decision to trust in an exchange relationship is not without risk, the potential benefits of trust will be lost if an alternate non trusting attitude is adopted (Whitener et al., 1998).

\section{Attribution Variables}

\section{Trustworthiness, reliability, communication and competence}

Levels of trustworthiness between project stakeholders was determined by attribution variables assigned to one another (Good, 1988). To this end, trustworthiness lay in the gift of those with whom they interacted-it could only be attributed to them by those who experienced it - and it commonly occurred only where mutually beneficial and collaborative approaches were married to clearly articulated common goals. Where this was expressed in hard dollar contract terms, informal "partnering" approaches to solving contractual issues were employed by those who were in a position to do so, or deliberately chose this approach. Hence, the mere presence of a traditional procurement mechanism was not shown to be an insurmountable barrier to trustbased solutions, and the benefits of trustworthiness were subsequently acknowledged (Gajendran et al., 2013; McLain and Hackman, 1995).

Where the voluntary exposure of a party to increased risk through the employment of trusting behaviour was betrayed, the consequences for that relationship were negative and long term. There was widespread expectation of reciprocation, and where this was not forthcoming it could impact upon decision-making during future projects - to be more reticent about informal partnering - or even the selection of future projects themselves. By extension, other characteristics attributable were found to be similarly influential. The reliability of trading partners, in terms of their ability to communicate efficiently and effectively (Gajendran et al., 2013), as well as the competence with which they completed their work were all frequently mentioned, both as positive attributes to be sorting trading partners and as inhibitors to project performance where their absence in trading partners was evident. Moreover, some interviewees reflected unfavourably upon their own ability to perform in these regards, principally in relation to communication; this was particularly evident where internal business processes and ICT systems hindered the timely communication of documents, thereby reducing their capacity to collaborate. Paradoxically, the increased use of ICT to improve the efficiency of project team communications was observed to hinder face-to-face contact, and this was felt to inhibit the opportunity to build trust and solve problems informally through collaboration.

A track record of the capacity to deliver results was universally acknowledged as a key factor in winning work and becoming the object of trust. Reputation and record with supply chain customers was regarded as crucial to the long-term health of businesses; conversely poor performance and/or incompetence were believed to be extremely damaging to a firm's reputation. 


\section{Benevolence, honesty, and integrity}

Characteristics of benevolence, honesty and integrity were identified in terms of attributional characteristics ascribed to trading partners, as well as in terms of characteristics displayed and self-identified by the interviewees themselves.

A willingness to act with benevolence in the interest of others (Lämsä and Pucetaite, 2006) was a common characteristic amongst the majority of those interviewed. It typically took the form of "going the extra mile", and doing things that were not strictly contractual, but that would nevertheless result in better - and more trusting - relationships, in the pursuit of better project outcomes (Lämsä and Pucetaite, 2006). Those that demonstrated benevolence did so in spite of, rather than as a result of, the legitimate opportunities to exploit their trading partners using contractual levers available to them. Similarly, the exercise of benevolence was found to be instrumental in reducing the negative impacts of contractual conflicts; the search for a win-win outcome was held to be preferable over a transactional win in court, when considered in terms of overall project success.

The issue of integrity - adherence to a known set of principles underpinning behaviour - was raised by some interviewees: the presence of integrity in stakeholder relationships was taken as indicative of the trustworthiness of the party displaying it. Conversely, actions displaying a lack of integrity by a particular party would quickly undermine relationships, shaping future decisions and tainting attitudes towards that party. In one instance a "charter of agreed values" was appended to a traditional contract in an attempt to better align the personal attitudes and actions of trading partners with the desired project outcomes.

Only a small number of the interviewees demonstrated an overt understanding of honesty and its influence in terms of developing and maintaining stakeholder relationships, and the consequent improvements in project outcomes. To this end, given that honesty and dishonesty were only scarcely identified as triggers and barriers to better relationships, a wider understanding in this regard would be beneficial.

\section{Contextual Variables}

\section{Risk, vulnerability, uncertainty and its control}

The need for trust in the first place is not only contingent upon the existence of two parties in an unequal power relationship, but also on the existence of a context within which that power structure places one or the other of these parties in a situation of risk and vulnerability. A strong theme that recurred through many interviews was the idea that the pre-existence of a strong and strategic relationship between trading partners was a powerful mechanism for reducing the initial levels of such risk and vulnerability. This was particularly the case for clients who would gauge the risk associated with alternative trading partners in terms of prior experience with repeat suppliers.

Contractual apportionment of risk, which was widely regarded as central to the nature of project outcomes (Schwalbe, 2004), could be dealt with to the satisfaction of all parties providing there were clear guidelines for its distribution from the outset. Conversely, where definitive risk apportionment and management was ambiguous, uncertainty prevailed, and trust diminished as a consequence. The presence of clear guidelines and definitive procedures for dealing with unforeseen risks were therefore considered to be significant. Traditional procurement mechanisms - even construct-only contracts - were not seen as detrimental to either party's interests so long as these mechanisms were in place from the outset; i.e. contractual remedies had to be appropriate, and appropriately implemented. However, no interviewee made any reference to trust itself as an appropriate risk/uncertainty mitigation technique (Wong et al., 
2007). This silence may indicate that an increased level of trust within stakeholder relationships could be beneficial in terms of managing project risk. However, it also supports the idea that it is the appropriate management of risk, more so than the trust amongst stakeholders that is integral to the success of traditionally procured projects. Paradoxically then, the human element was seen as being of equal, and perhaps even greater significance to the likelihood of successful outcomes when dealing with unforeseen risk and uncertainty than the control mechanisms themselves. While the control mechanisms would provide the boundary within which project stakeholders interacted under conditions of uncertainty and risk, it was the attitudes and behaviours of the personalities involved that ultimately determined the success of any contractual arrangements. It was therefore widely felt that relationship-based negotiation was preferable to contract-based actions.

Ultimately, while the respective control mechanism in any project will influence stakeholder relationships and project outcomes, appropriate allocation and management of risk, along with the individual stakeholders involved will likely be of greater consequence.

\section{Team environment}

If the foregoing could be said to apply to individuals representing various stakeholders within the project team, the overall project team environment was also seen as being crucial to achieving successful project outcomes. Shared values, competent and timely communication, appropriate managerial leadership, and mutual respect were all recognised to contribute to a positive project team culture, leading to collaborative problem-solving when unforeseen circumstances arose. However, the link between individual personalities and overall project team culture could not be ignored, and some interviewees blamed difficult projects which led to poor outcomes on a clash of personalities between key individuals. Ultimately, a positive team environment was considered vital for project success, however, while none the less implied in the parallel between a positive team environment and good stakeholder relationships, a greater recognition of the specific value of trust and its dimensions in this regard (Delisle, 2004) would be useful within a traditional procurement context.

\section{Trust, projects and project outcomes}

The interviewees demonstrated an implicit understanding regarding the influence of trust on cooperative processes (Kramer, 1999), and successful project outcomes (Pinto, Slevin and English, 2008). However, this acknowledgment was overtly limited to other dimensions of trust rather than trust itself. Similarly, project characteristics pertaining to a limited timeframe (Hartman, 2002), as well as a general lack of opportunity for multiple interactions (Dervitsiotis, 2003), were not explicitly acknowledged in terms of trust and its influence (Atkinson, Crawford and Ward, 2006). Project supply chains inherently necessitate trust-building on an all-toofrequent basis. Hence it may be suggested that stakeholders view trust building as being too hard as a matter of routine, and that trusting/trusted relationships with strategic trading partners arise more by chance than by design or strategy.

\section{Trust Failure}

\section{Trust break down and repair}

The potential for negative events and a breakdown of trust within traditionally procured projects was universally acknowledged by the interviewees, with reduced project outcomes the result. However, in terms of repairing lost trust, while the interviewees acknowledged the benefits of strong relationships when resolving conflicts and responding to negative events, there was no 
demonstrated understanding of the intricacies of trust repair itself, or how the trust repair process differs from initial trust development (Kim et al., 2004). In this regard, there was little evidence that any of the interviewees had considered the possibility of actively repairing and rebuilding relationships with trusted trading partners in the event that they failed for some reason. This appeared to suggest that whilst trust was beneficial and desirable it wasn't sufficiently valuable to invest time and effort in sustaining a trusted relationship through a rough patch.

\section{Discussion}

The results obtained from this interview-based study into the influence of trust upon project outcomes within traditionally procured projects have shown that whilst trust is not, and cannot be mandated through contractual instruments, those individuals forced to work within this context recognise its value. That is to say, project participants occupying positions within the top tiers of project teams routinely employ, and experience approaches to solving problems associated with risk and uncertainty that are trusting in nature. They and their counterparts appear to be willing to accept heightened levels of short-term risk and vulnerability (by trusting, and being trusted) in order to solve larger issues of contractual vulnerability, risk, and uncertainty.

Given that trust must necessarily occur at the level of individuals, whereas contracts apply to trading entities, it can be seen that for trust to occur there is a form of risk transfer: the individual negotiators assume much heightened personal, though informal, liability, in the hope that their actions will lead to mutually acceptable collaborative outcomes. In a personal sense, these individual risk takers are engaging in the search for unique solutions to unique problems (i.e. the sources and consequences of unforeseen contractual risks). On one level the solutions could be thought of as being innovative - novel ideas that might lead to advantageous outcomes, over and above normal expectations - and bring with them the risks associated with innovating (particularly failure).

Previous research into the attitudinal characteristics of decision-makers in the construction sector has revealed that whilst stakeholders consider and balance salient issues during their deliberations, their decisions are tempered by issues of personal risk - to ongoing employment, reputation, personal return on investment and so on. It is in the context of these personal risks that both trusters and trustees have to consider another innovation concept, namely affordable loss.

Innovative firms, and to a lesser extent innovative individuals, often balance their desire to seek extraordinary profit through innovation against the costs of doing so and the likelihood of its success. Like the prudent gambler, they will have a budget or stake money which they are prepared to lose. This affordable loss then dictates the point at which they are prepared to cut their losses and walk away. The same is often true of corporate entities engaged in litigation over contractual disputes. However, when it comes to individual employees considering engaging in a trust-based relationship with a potential adversarial litigant in the hope of negotiating a mutually favourable outcome, an additional level of affordable loss is introduced. Any decision to trust brings with it a heightened risk of failure and the potential for ridicule, loss of reputation, reduced employability, and so on. This is particularly the case for traditionally procured projects when no provision is made for negotiated variations or outcomes: the risk is wholly personal.

Ultimately, while individual stakeholders may recognise the benefits of trust and it's dimensions, the perceived affordable loss may be deemed too great, and consequently dictate actions and behaviours which ignore the potential benefits forthcoming through a trusting response to risk. Or similarly, the "you first attitude" may apply, and individuals become reticent to accept the risk 
associated with a decision to trust, without first experiencing trust themselves. The potential benefits of trust in response to risk may therefore never be realised, with sub optimal project outcomes the result.

\section{Conclusion}

It was clear that trust issues frequently influenced the lived experiences of stakeholders within traditionally procured projects. Trust through its various dimensions was both an explicit and implicit influence on stakeholder relationships, transactions and eventual project performance. Trust issues were found to trigger both good and bad relationships. Yet despite its centrality, there was little evidence of proactive actions to develop and maintain trust within traditionally procured projects. A greater understanding of why this was the case would be beneficial.

Individual stakeholders were found to be a significant influence on project outcomes, with issues of trust fundamental in this regard. The past experiences and initial attitude of stakeholders were shown to be influential to project success. This indicated the importance of a) initiating actions to develop stakeholder trust during project initiation, and b) adopting a focused approach to trading partner selection on the basis of trust compatibility and consequent value delivery, rather than cost alone. Given that individual personalities within the project team were the triggers to (non) trust, characteristics of competence, honesty, benevolence, and trustworthiness would be vital, along with willingness for open communication and a cooperative approach to resolving issues when they arose.

Traditional procurement mechanisms are not inherently conducive to informal communication and problem-solving, yet personal traits espousing this approach were commonly acknowledged as desirable attributes, likely to contribute to project success. In spite of this, most stakeholders were not willing to expose themselves to the increased risk that came with informality, usually to the detriment of project outcomes. Mechanisms specifically designed to reduce contractual risk through informality would appear to offer the potential for considerable benefit.

The appropriate identification, allocation and management of risk within traditionally procured projects were also found to be vital. While there was some acknowledgement of the parallel between trust and risk, it was apparent that while increased levels of trust may help overcome risk, it is the allocation of the risk in the first instance that is of greater importance. This holds true in spite of the chosen procurement method, and has particular relevance to the design and implementation of traditional procurement mechanisms.

There was widespread awareness of the potential for negative events and a subsequent break down in trust within traditionally procured projects. There was also an apparent understanding of the value of strong relationships and trust when responding to negative events and resolving conflict. However, there was no evidence that project participants understood precursor triggers to poor relationships and distrust, which in turn led to poor project performance. Nor was they any awareness regarding the importance of and mechanisms to, repairing relationships once trust had been lost. This appears indicative of both an undervaluing of trust as a tool for project performance, and a comfort in retreating to traditional contractual remedies.

This study has illuminated the development and maintenance of trust within the lived experiences of construction practitioners operating in traditionally procured projects, while also highlighting the potential short comings of the traditional procurement mechanism. To this end, a greater understanding from stakeholders regarding trust and its dimensions would be advantageous, both in terms of procurement mechanism design, as well as practical application. 


\section{References}

Atkinson, R., Crawford, L. and Ward, S., 2006. Fundamental uncertainties in projects and the scope of project management. International Journal of Project Management, 24(8), pp.687-98. doi: http://dx.doi.org/10.1016/i.ijproman.2006.09.011

Aubert, B.A. and Kelsey, B.L., 2000., The illusion of trust and performance [Online]. CIRANO. Available at: http://www.cirano.qc.ca/pdf/publication/2000s-03.pdf [Accessed 27 April 2009].

Becerra, G., Denzinger, J. and Kremer, R., 2001. Can You Trust Your Trust Model [Online]. Department of Computer Sciences-University of Calgary. Available at: http://pages.cpsc.ucalgary.ca/ ayala/conference/Trust_Type_Project.pdf [Accessed 23 April 2009.

Bigley, G.A. and Pearce, J.L., 1998. Straining for shared meaning in organisation science: Problems of trust and distrust. Academy of Management Review, 23(3), pp.405-21.

Brewer, G. and Strahorn, S., 2012. Trust and the Project Management Body of Knowledge. Engineering, Construction and Architectural Management, 19(3), pp.286-305. doi: http://dx.doi.org/10.1108/09699981211219616

Campbell, D., 2004. "Ian Macneil and the Relational Theory of Contract. Center for Legal Dynamics of Advanced Market Societies (CDAMS) Discussion Paper, Kobe University.

Chan, A.P., Chan, D.W., Fan, L.C., Lam, P.T. and Yeung, J.F., 2006. Partnering for construction excellence - A reality or Myth. Building and Environment, 41(12), pp.1924-33. doi: http://dx.doi.org/10.1016/i.buildenv.2005.06.026

Chan, A.P., Chan, D.W. and Ho, K.S., 2003. An empirical study of the benefits of construction partnering in Hong Kong. Construction Management and Economics, 21(5), pp.523-33. doi: http://dx.doi.org/10.1080/0144619032000056162

Chen, W.T. and Chen, T.T., 2007. Critical success factors for construction partnering in Taiwan. International Journal of Project Management, 25(5), pp.475-84. doi: http://dx.doi.org/10.1016/i.ijproman.2006.12.003

Chow, P.T., Cheung, S.O. and Chan, K.Y., 2012. Trust-building in construction contracting: Mechanism and expectation. International Journal of Project Management, 30(8), pp.927-37. doi: http://dx.doi.org/10.1016/j.ijproman.2012.03.002

Cresswell, J.W. and Plano Clark, V.L., 2007. Designing and Conducting Mixed Methods Research, Thousand Oaks, CA: Sage Publications.

Delisle, C. 2004. Contemporary views on shaping, developing, and managing teams. In: Morris PWG and Pinto JK (eds.) The Wiley guide to managing projects. Hoboken, NJ: John Wiley. doi: http://dx.doi.org/10.1002/9780470172391.ch39

Dervitsiotis, K.N., 2003. Beyond stakeholder satisfaction: aiming for a new frontier of sustainable stakeholder trust. Total Quality Management, 14(5), pp.515-28. doi: http://dx.doi.org/10.1080/1478336032000053555

Eisenhardt, K.M., 1989. Building theories from case study research. Academy of Management Review, 14(4), pp.532-50. doi: http://dx.doi.org/10.5465/AMR.1989.4308385 and http://dx.doi.org/10.2307/258557

Forgues, D. and Koskela, L., 2009. The influence of a collaborative procurement approach using integrated design in construction on project team performance. International Journal of Managing Projects in Business, 2(3), pp.370-85. doi: http://dx.doi.org/10.1108/17538370910971036

Gajendran, T., Brewer, G., Jefferies, M. and Strahorn, S., 2013. An evaluation of philosophical disposition and operational reality of 'alliances': the risk-trust perspective. RICS COBRA 2013. Proceedings of RICS COBRA 2013 New Delhi, India 10-12 September, 2013: Royal Institution of Chartered Surveyors.

Good, D., 1988. Individuals, interpersonal relations and trust. In: Gambetta D. (ed.) Trust: making and breaking cooperative relations. New York: Blackwell.

Hartman, F.T., 1999. The role of trust in project management. PMI Research Conference, 1999.

Hartman, F.T., 2002. The role of trust in project management. In: Slevin DP, Cleland DI and Pinto JK (eds.) The frontiers of project manageemnt research. Newtown Square, PA: Project Management Institute.

Ibrahim, C.K.C., Costello, S.B. and Wilkinson, S., Key Practice Indicators of Team Integration in Construction Projects: A Review. 2011 2nd International Conference on Construction and Project Management, 2011. Singapore: IACSIT Press.

Karlsen, J.T., Græe, K. and Massaoud, M.J., 2008. Building trust in project-stakeholder relationships. Baltic Journal of Management, 3(1), pp.7-22. doi: http://dx.doi.org/10.1108/17465260810844239

Kim, P.H., Dirks, K.T., Cooper, C.D. and Ferrin, D.L., 2006. When more blame is better than less: The implications of internal vs. external attributions for the repair of trust after a competence- vs. integrity-based trust violation. Organizational Behavior and Human Decision Processes, 99(1), pp.49-65. doi: http://dx.doi.org/10.1016/i.obhdp.2005.07.002

Kim, P.H., Ferrin, D.L., Cooper, C.D. and Dirks, K.T., 2004. Removing the shadow of suspicion: The effects of apology versus denial for repairing competence- versus integrity- based trust violations. Journal of Applied Psychology, 89(1), pp.104-18. doi: http://dx.doi.org/10.1037/0021-9010.89.1.104 
Kramer, R.M., 1999. Trust and distrust in organisations: emerging perspectives, enduring questions. Annual Review of Psychology, 50(1), pp.569-98. doi: http://dx.doi.org/10.1146/annurev.psych.50.1.569

Lämsä, A.M. and Pucetaite, R., 2006. Development of organisational trust among employees from a contextual perspective. Bussiness Ethics: A European Review, 15(2), pp.130-41.

Lander, M.C., Purvis, R.L., McCray, G.E. and Leigh, W., 2004. Trust building mechanisms utilised in outsourced IS development projects: a case study. Information and Management, 41(4), pp.509-28. doi: http://dx.doi.org/10.1016/i.im.2003.10.001

Lewicki, R.J. and Bunker, B.B., 1996. Developing and maintaining trust in work relationships. In: Kramer, R.M. and Tyler, T.R. (eds.) Trust in organizations: Frontiers of theory and research. Thousand Oaks, CA: Sage. doi: http://dx.doi.org/10.4135/9781452243610.n7

Macneil, I.R., 1978. Contracts: Adjustment of long-term economic relations under classical, neoclassical and relational contract law. Northwest University Law Review, 72(2), pp.854-905.

Mayer, R., Davis, C. and Schoorman, F., 1995. An integrative model of organisational trust. Academy of Management Review, 20(3), pp.709-34. doi: http://dx.doi.org/10.2307/258792 and http://dx.doi.org/10.5465/AMR.1995.9508080335

McInnis, A., 2003., Relational Contracting Under the New Engineering Contract: A Model, Framework, and Analysis. Society of Construction Law, UK, D037 [online] Available at: http://www.scl.org.uk/node/766.

McKnight, D.H. and Chervany, N.L., 1995. Trust building processes in organisational relationships. In: Ragsdale CT, Houck EC and Sumichrast RT (eds.) Proceedings Decision Sciences Institute: 1995 Annual Meeting. Boston MA.

McKnight, D.H., Cummings, L.L. and Chervany, N.L., 1998. Initial trust formation in new organizational relationships. Academy of Management Review, 23(3), pp.473-90. doi: http://dx.doi.org/10.2307/259290 and http://dx.doi.org/10.5465/AMR.1998.926622

McLain, D.L. and Hackman, B.K., 1995. Trust and risk taking in organisations. Public Administration Quarterly, 23(2), pp.152-76.

Meyerson, D., Weick, K. and Kramer, R., 1996. Swift trust and temporary groups. In: Kramer, R. and Tyler, T. (eds.) Trust in organizations: Frontiers of theory and research. Thousand Oaks, CA.: Sage. doi: http://dx.doi.org/10.4135/9781452243610.n9

Misztal, B.A., 1996. Trust in modern societies. Cambridge: Polity Press.

Mosey, D., 2003. "PPC 2000: The First Standard Form of Contract for Project Partnering". Society of Construction Law, $U K$.

Munns, A.K., 1995. Potential influence of trust on the successful completion of a project. International Journal of Project Management, 13(1), pp.19-24. doi: http://dx.doi.org/10.1016/0263-7863(95)95699-E

Ng, S.T., Rose, T.M., Mak, M. and Chen, S.E., 2002. Problematic issues associated with partnering- the contractor perspective. International Journal of Project Management, 20(6), pp.437-49. doi: http://dx.doi.org/10.1016/S02637863(01)00025-4

Pesämaa, O., Eriksson, P.E. and Hair, J.F., 2009. Validating a model of cooperative procurement in the construction industry. International Journal of Project Management, 27(6), pp.552-59. doi: http://dx.doi.org/10.1016/i.ijproman.2008.10.007

Pike, Kenneth L., 1967. Language in relation to a unified theory of the structures of human behavior (2nd ed.). The Hague: Mouton. doi: http://dx.doi.org/10.1515/9783111657158

Pinto, J.K., Slevin, D.P. and English, B., 2008. Trust in projects: An empirical assessment of owner/contractor relationships. International Journal of Project Management, 27(6), pp.638-48. doi: http://dx.doi.org/10.1016/i.ijproman.2008.09.010

PMI 2008. A Guide to the Project Management Book of Knowledge (PMBOK Guide)- Fourth Edition, Newtown Square, PA: Project Management Institute.

Rahman, M.M. and Kumaraswamy, M.M., 2004. Contracting Relationship Trends and Transitions. Journal of Management in Engineering, 20(4), pp.147-61. doi: http://dx.doi.org/10.1061/(ASCE)0742-597X(2004)20:4(147)

Romahn, E. and Hartman, F., Trust: A New Tool for Project Managers. Proceedings of the 30th Annual Project Management Institute 1999 Seminars and Symposium. 10-16 October 1999. Philadelphia, Pennsylvania, USA.

Rosseau, D.M., Sitkin, B., Burt, R.S. and Camerer, C., 1998. Not so different after all: a cross-discipline view of trust. Academy of Management Review, 23(3), pp.393-404. doi: http://dx.doi.org/10.5465/AMR.1998.926617

Sakal, M.W., 2005. Project Alliancing: A Relational Contracting Mechanism for Dynamic Projects. Lean Construction Journal, 2(1), pp.67-79.

Schwalbe, K., 2004. Information Technology Project Management. Third edition, Course Technology, Thompson.

She, L., 2013. Trust, mistrust and distrust in alliancing. In: Smith, S.D. and Ahiaga-Dagbui, D.D., (eds.) Procs 29th Annual ARCOM Conference 2-4 September 2013. Reading, UK: Association of Researchers in Construction Management, pp.1001-11.

Sheppard, B.H. and Sherman, D.M., 1998. The grammars of trust: a model and general implications. Academy of Management Review, 23(3), pp.422-37. doi: http://dx.doi.org/10.5465/AMR.1998.926619 and

http://dx.doi.org/10.2307/259287 
Sitkin, S.B. and Roth, N.L., 1993. Explaining the limited effectiveness of legalistic "remedies" for trust/distrust. Organisaitonal Science, 4(3), pp.367-92. doi: http://dx.doi.org/10.1287/orsc.4.3.367

Slovic, P., 1993. Perceived risk, trust, and democracy. Risk. Analysis, 13(6), pp.675-82. doi: http://dx.doi.org/10.1111/j.1539-6924.1993.tb01329.x

Strahorn, S., Thayaparan, G. and Brewer, G., 2013. Mechanisms of trust and trust repair in relational contracting: a multiple perspective investigation of alliance projects. CIB World Congress 2013. Brisbane, Australia.

Tomlinson, E.C. and Mayer, R.C., 2009. The role of casual attribution dimensions in trust repair. Academy of Management Review, 34(1), pp.85-104. doi: http://dx.doi.org/10.5465/AMR.2009.35713291

Weiner, B., 1986. An attributional model of motivation and emotion, New York: Springer-Verlag. doi: http://dx.doi.org/10.1007/978-1-4612-4948-1

Weiner, B., 2001. Responsibility for social transgressions: An attributional analysis. In: Malle, B.F., Moses, L.J. and Baldwin, D.A. (eds.) Intentions and intentionality: Foundations of social cognition. Cambridge, MA: MIT Press.

Wertz, F.J., Charmaz, K., McMullen, L.M., Josselson, R., Anderson, R. and McSpadden, E., 2011. Five ways of doing qualitative analysis: Phenomenological psychology, grounded theory, discourse analysis, narrative research, and intuitive inquiry, New York: Guilford Press.

Whitener, E.M., Brodt, S.E., Korsgaard, M.A. and Werner, J.M., 1998. Managers as initiators of trust: An exchange relationship framework for understanding managerial trustworthy behaviour. Academy of Management Review, 23(3), pp.513-30. doi: http://dx.doi.org/10.5465/AMR.1998.926624 and http://dx.doi.org/10.2307/259292

Wicks, A.C., Berman, S.L. and Jones, T.M., 1999. The structure of optimal trust: moral and strategic implications. Academy of Management Review, 24(1), pp.99-119. doi: http://dx.doi.org/10.2307/259039 and http://dx.doi.org/10.5465/AMR.1999.1580443

Wong, W.K., Cheung, S.O., Yiu, T.W. and Pang, H.Y., 2007. A framework for trust in construction contracting. International Journal of Project Management, 26(8), pp.821-29. doi: http://dx.doi.org/10.1016/j.ijproman.2007.11.004

Wood, G. and McDermott, P., 1999. Building on trust: A co-operative approach to construction procurement. Journal of Construction Procurement, 7(2), pp.4-14.

Yeung, J.F.Y., Chan, A.P.C. and Chan, D.W.M., 2007. The definition of alliancing in construction as a Wittgenstein family-resemblance concept. International Journal of Project Management, 25(3), pp.219-31. doi: http://dx.doi.org/10.1016/j.ijproman.2006.10.003

Yiu, K.T. and Cheung, S.O., 2007. A study of construction mediator tactics - Part II: The contingent use of tactics. Building and Environment, 42(2), pp.762-69. doi: http://dx.doi.org/10.1016/i.buildenv.2005.09.005 


\section{Appendix}

Table 2: Condensed summary of interviewee quotations

\begin{tabular}{|c|c|}
\hline $\begin{array}{l}\text { Thematic Trust Framework } \\
\text { (Main Theme Codes) }\end{array}$ & Interviewee quotations (condensed summary) \\
\hline \multicolumn{2}{|l|}{ HUMAN VARIABLES } \\
\hline $\begin{array}{l}\text { Relationships, trust and the } \\
\text { project environment }\end{array}$ & 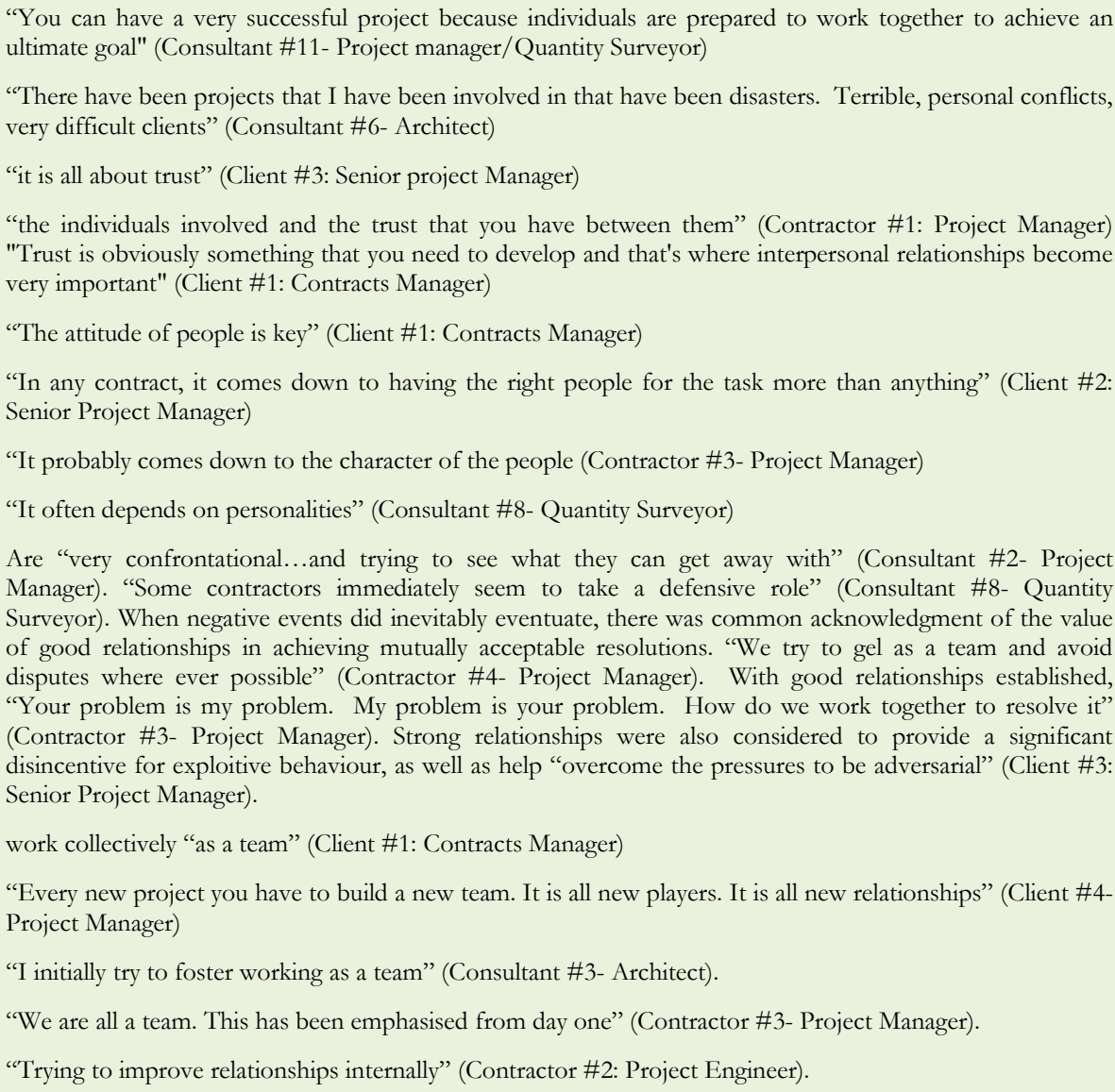 \\
\hline $\begin{array}{l}\text { Relationship interactions and } \\
\text { trust }\end{array}$ & $\begin{array}{l}\text { "There is a relationship there. It plays a big part" (Contractor \#2: Project Engineer) } \\
\text { "There are real benefits working with people who you know you are comfortable and confident working } \\
\text { with" (Consultant \#13- Engineer) } \\
\text { "We would like to work with them again. It is very important for us to maintain our relationship" } \\
\text { (Contractor \#3- Project Manager) } \\
\text { "9/10 people would be paranoid into the future that this would happen again" (Contractor \#1" Project } \\
\text { Manager) } \\
\text { "There were a few issues...so that left a bit of a sour taste in our mouth" (Contractor \#5- Project Manager) } \\
\text { "I would be happy to work with you again" (Consultant \#1: Project Manager) } \\
\text { "I tend to stay away from people who are difficult to work with interpersonally" (Client \#1: Contracts } \\
\text { Manager) } \\
\text { "If we do not achieve a successful outcome...I have no doubt that would be the last project we would work } \\
\text { on for the client" (Consultant \#11- Project manager/Quantity Surveyor) } \\
\text { "The client is a little bit wary of what happened in the past on projects" (Consultant \#11- Project } \\
\text { manager/Quantity Surveyor) } \\
\text { "There is a lot of loyalty and relationships have been built up" (Subcontractor \#2- Internal partitions and } \\
\text { linings) } \\
\text { "You get to know them. A lot of the work up here is done more on trust" (Contractor \#5- Project Manager) } \\
\text { "You got your name recognised by doing a good job" (Consultant \#8- Quantity Surveyor) } \\
\text { "If you good job, a good project, it might flow through to future work" (Consultant \#5- Quantity }\end{array}$ \\
\hline
\end{tabular}




\begin{tabular}{|c|c|}
\hline & $\begin{array}{l}\text { Surveyor) } \\
\text { "If all parties are happy...potentially there is another project to walk into the next time around" } \\
\text { (Subcontractor \#1- Electrical Services) } \\
\text { "People need to be respected and treated well" (Client \#1: Contracts Manager) } \\
\text { "If you can trust them, you can call them up at any time and ask them their opinion" (Consultant \#4- } \\
\text { Engineer) } \\
\text { "It is pretty much a collaborative approach. People working in isolation will not produce the best result" } \\
\text { (Consultant \#7- Engineer) } \\
\text { "A lot of it is to do with a bit of history" (Client \#3: Senior Project Manager) } \\
\text { "There is not a period of getting to know you. You can start already understanding the way things happen" } \\
\text { (Consultant \#12- Architect) } \\
\text { "Through previous dealings, we developed a reasonable relationship" (Subcontractor \#3- Elevator Services) } \\
\text { "Living together, working together" (Client \#2: Senior Project Manager) } \\
\text { "You can have some big conflicts" } \\
\text { "It is all about managing those relationships" (Contractor \#2: Project Engineer) }\end{array}$ \\
\hline $\begin{array}{l}\text { The initial intent of project } \\
\text { stakeholders }\end{array}$ & $\begin{array}{l}\text { "Initially it was quite contractual" (Contractor \#4- Project Manager) } \\
\text { "We have a culture of dealing very much in a collaborative way" (Consultant \#7- Engineer) } \\
\text { "With older generations...there is an us versus them mentality" (Consultant \#1: Project Manager) } \\
\text { "It could be a generational thing" (Client \#3: Senior Project Manager) } \\
\text { "It took us time to break down the us against them attitudes and try and get everybody working as one team. } \\
\text { I think we are at the position now where everybody is working towards a common goal which is extremely } \\
\text { important for the project" (Contractor \#4- Project Manager) } \\
\text { "When the contracts began...it was quite contractually aggressive. I have really tried to break that down" } \\
\text { (Contractor \#4- Project Manager) }\end{array}$ \\
\hline \multicolumn{2}{|l|}{ ATTRIBUTIONAL VARIABLES } \\
\hline Trustworthiness & $\begin{array}{l}\text { "Even though it is the traditional hard dollar contract....you try and help the contractor as much as you } \\
\text { can". "You partner your way through it....if there is an issue" (Client \#2: Senior Project Manager) } \\
\text { "It was a true relationship based arrangement. I don't think we ever looked at the contract" (Client \#4- } \\
\text { Project Manager) } \\
\text { "They are very quick to charge a variation and extremely slow to give any reduction. That is a real sore point } \\
\text { and it gets to the point it is quite adversarial" (Consultant \#6- Architect) } \\
\text { "You are not going to be bidding for work" (Client \#3: Senior Project Manager) } \\
\text { "I would never get involved with another job like that" (Subcontractor \#3- Elevator Services) }\end{array}$ \\
\hline Reliable behaviour & $\begin{array}{l}\text { "We tend to have our preferred list of people we would rather work with, based on experience" (Consultant } \\
\text { \#7- Engineer) } \\
\text { "We have a core group of each trade that we use almost exclusively" (Contractor \#5- Project Manager) } \\
\text { Relationships are negatively influenced by "unreliability" (Client \# 1: Contracts Manager) and "poor } \\
\text { behaviour" (Client \#3" Senior Project Manager) } \\
\text { "You are not going to be bidding for (future) work" (Client \# 3: Senior Project Manager) }\end{array}$ \\
\hline Communication & $\begin{array}{l}\text { "I initially try to foster communication and working as a team" (Consultant \#3- Architect) } \\
\text { "There is no doubt that communication is the key" (Consultant \#4- Engineer) } \\
\text { "If there are issues, you have just got to bring them out in the open and discuss them" (Client \#2: Senior } \\
\text { Project Manager) } \\
\text { "The project team must get together, and thrash any issues out" (Contractor \#4- Project Manager) } \\
\text { "If there is close communication, a lot of problems can be resolved before they actually become a problem. } \\
\text { These are the kind of projects you want to work on" (Consultant \#7- Engineer) } \\
\text { "If we had a bit more freedom of information... a lot of the problems we have to face day after day would be } \\
\text { alleviated" (Subcontractor \#2- Internal partitions and linings) } \\
\text { "Open communication is good" (Client \#3: Senior Project Manager) } \\
\text { "We need to communicate very freely and openly" (Consultant \#7- Engineer) }\end{array}$ \\
\hline
\end{tabular}




\begin{tabular}{|c|c|}
\hline & $\begin{array}{l}\text { "Everyone is cooperating. Everyone is getting on well, getting answers back on questions very promptly" } \\
\text { (Contractor \#3- Project Manager) } \\
\text { "If there is no communication, a job will stop" (Contractor \#2: Project Engineer) } \\
\text { "We have an almost interconnecting corridor....You can see them and you can go and sit down and talk to } \\
\text { them" (Client \#2: Senior Project Manager) } \\
\text { "My door is always open so it is always coming in and speaking about any issues" (Subcontractor \#1- } \\
\text { Electrical Services). } \\
\text { "Number one preference is to go and see the client face to face" (Consultant \#1: Project Manager) } \\
\text { "Try to keep resolutions of issues as informal as possible....So talk before you write letters" (Client \#1: } \\
\text { Contracts Manager) } \\
\text { "I find the best way to resolve problems is to pick the phone up and talk to them" (Contractor \#4- Project } \\
\text { Manager) } \\
\text { "It is more important to be out there on site, physically talking to people. Sorting out problems in person" } \\
\text { (Subcontractor \#1- Electrical Services) } \\
\text { "I would rather discuss it as opposed to sending an email which can often be received abruptly" (Consultant } \\
\text { \#11- Project manager/Quantity Surveyor) } \\
\text { "There has been a fair amount of frustration. It is often difficult to interact (with this client) because they are } \\
\text { fairly bureaucratic. It is often difficult to get answers" (Consultant \#10- Client Representative) } \\
\text { "We have internal quality assurance procedures here which in some way hinder collaboration in terms of } \\
\text { transferring documents and so on" (Consultant \#12- Architect) } \\
\text { "We do not sit down and talk and interface to the degree we use to. That interpersonal face to face stuff is } \\
\text { "bert the build up a level of trust" (Consultant \#8- Quantity Surveyor) }\end{array}$ \\
\hline Competence & $\begin{array}{l}\text { "We were not the cheapest by far, but they still gave us the job because they know we can deliver it" } \\
\text { (Contractor \#2: Project Engineer) } \\
\text { "There was a reputation....Someone known for not delivering quality of work" (Contractor\#2: Project } \\
\text { Engineer) } \\
\text { "They would not be employing us if they did not think that we could get the job done" (Consultant \#2- } \\
\text { Project Manager) } \\
\text { "can often influence the next job" (Consultant \#10- Client Representative) } \\
\text { "You tend to just stay with them unless something goes wrong" (Contractor \#2: Project Engineer) } \\
\text { "If you have done it, they will trust you and they will give you more work" (Contractor \#2: Project } \\
\text { Engineer) } \\
\text { "If you do not do a good job or do not do it right, then you are out of business tomorrow" (Subcontractor } \\
\text { \#3- Elevator Services) }\end{array}$ \\
\hline Benevolence & $\begin{array}{l}\text { "The courteous phone call to say we are going to do this and it is going to affect you is not required by me. } \\
\text { But I will do it. It does build a good relationship" (Subcontractor \#2- Internal partitions and linings) } \\
\text { "Each party needs to acknowledge the other's goals" (Client \#1: Contracts Manager) } \\
\text { "I am helping you and you are helping me" (Client \#4- Project Manager) } \\
\text { "There should be a bit of give and take" (Consultant \#6- Architect) } \\
\text { Exploitive behaviour "cruels your relationship" (Consultant \#1: Project Manager) } \\
\text { "Even though it is a hard dollar contract....I have always been of the opinion that you try and help the } \\
\text { contractor as much as you can.....so you are not sending him bankrupt by sticking to the rules" Client \#2: } \\
\text { Senior Project Manager) } \\
\text { "We are working together to fix it. It is not "you have made a mistake. Rip it out" (Client \#4- Project } \\
\text { Manager) } \\
\text { "At the end of the day we wanted the project to be successful for everybody" (Consultant \#11- Project } \\
\text { manager/Quantity Surveyor) }\end{array}$ \\
\hline Integrity & $\begin{array}{l}\text { "He tabled these drawings. They were our drawings only rebadged. It was terrible" (Client \#4- Project } \\
\text { Manager) } \\
\text { "Shared values" (Contractor \#1: Project Manager) were considered instrumental, particularly during the } \\
\text { initial stages of a relationship } \\
\text { "a charter of agreed values" (Contractor \#1: Project Manager) was drafted at the commencement of a }\end{array}$ \\
\hline
\end{tabular}




\begin{tabular}{|c|c|}
\hline & contract, in an attempt to foster the right type of individual \\
\hline Honesty & $\begin{array}{l}\text { "Honesty is the most important thing" (Contractor \#1: Project Manager) } \\
\text { "dishonesty" (Client \#1: Contracts Manager) negatively influences a relationship } \\
\text { "honest" (Contractor \#1: Project Manager) behaviour fosters trust }\end{array}$ \\
\hline \multicolumn{2}{|l|}{ CONTEXTUAL VARIABLES } \\
\hline $\begin{array}{l}\text { Risk, vulnerability and } \\
\text { uncertainty }\end{array}$ & $\begin{array}{l}\text { "It is less risk giving it to us than having to bring in a new company, and establish that client relationship" } \\
\text { (Contractor \#2: Project Engineer) } \\
\text { "We have been working with the client for so long anyway, so it was it was really 'how can we assist you'. } \\
\text { The relationship was already there" (Consultant \#3- Architect) } \\
\text { "We understand how they work. We understand where the risks are and try and manage our way through } \\
\text { that process" (Consultant \#3- Architect) } \\
\text { "Sometimes in a hard dollar environment, if they are starting to not perform well and lose money it can } \\
\text { become adversarial" (Client \#3: Senior Project Manager) } \\
\text { "The risk that the clients are asking us to take on is getting greater and greater. It really is a concern" } \\
\text { (Contractor \#4- Project Manager) } \\
\text { "If you do not get the principles and project requirements absolutely bullet proof you lose control" (Client } \\
\text { \#4- Project Manager) } \\
\text { "We have eliminated the risk, even if it is construct-only" (Client \#3: Senior Project Manager) } \\
\text { "If you have got clear guidelines it is quite easy to give clear outputs" (Consultant \#2- Project Manager) } \\
\text { "try and reduce their own internal risks on a project from their own point of view" (Consultant \#5- Quantity } \\
\text { Surveyor) } \\
\text { "As long as we have identified the risk and we have made allowances for it" we can avoid "adversarial", and } \\
\text { "contractual head bashing" (Client \#3: Senior Project Manager) } \\
\text { "We get what we want. It is just a much fairer way of doing it" (Client \#3: Senior Project Manager) }\end{array}$ \\
\hline Control mechanisms & $\begin{array}{l}\text { "The contract itself can establish or disestablish a relationship" (Consultant \#1: Project Manager) } \\
\text { "Even though it is construct-only you can identify where the risks are and assist in making it fair" (Client \#3: } \\
\text { Senior Project Manager) } \\
\text { "the personalities involved" (Contractor \#1: Project Manager) } \\
\text { "People are always key, but the different styles of contract procurement can place certain pressures on the } \\
\text { team that can put a lot more tension in relationships" (Client \#1: Contracts Manager) } \\
\text { "In any contract it comes down to having the right people for the task more than anything" (Client \#2: } \\
\text { Senior Project Manager) } \\
\text { "There is a contractual process in place. It has to be there. It has to be used to manage risk. However, if you } \\
\text { get that relationship going with the guys that matter you are fine" (Client \#4- Project Manager) } \\
\text { "It was a true relationship based arrangement. I don't think we ever looked at the contract" (Client \#4- } \\
\text { Project Manager) } \\
\text { "I find that you get far better outcomes if we are not just quoting contract clauses at each other all the time" } \\
\text { (Contractor \#4- Project Manager) } \\
\text { "It was a collaborative approach. I cannot see any other way of doing it" (Consultant \#6- Architect) } \\
\text { Project success relies on "the character of people" (Contractor \#3- Project Manager) and the "driving force } \\
\text { of certain personalities" (Consultant \#10- Client Representative) } \\
\text { A strictly contractual approach often lead to situations that were "very confrontational" (Consultant \#2- } \\
\text { Project Manager) and "totally aggressive"( Consultant \#5- Quantity Surveyor) } \\
\text { "We had a couple of issues that had to go through the dispute resolution process and that was a fairly painful } \\
\text { process for everyone" (Contractor \#4- Project Manager) } \\
\text { "The formal contract does not build trust. The building of trust and relationships, etc. etc. - it is all the } \\
\text { informal process" (Client \#3: Senior Project Manager) }\end{array}$ \\
\hline Team environment & $\begin{array}{l}\text { "common agreement” (Consultant \#3- Architect) facilitates a positive team environment } \\
\text { "If people are happy, people are productive" (Contractor \#2: Project Engineer) } \\
\text { "huge economic benefit as well” (Client \#1: Contracts Manager) } \\
\text { "good leadership and mentorship" will "develop a culture of willingness to discuss things and work things }\end{array}$ \\
\hline
\end{tabular}




\begin{tabular}{|c|c|}
\hline & $\begin{array}{l}\text { through" (Client \#1: Contracts Manager) } \\
\text { "It is very collaborative. This had been emphasised from day one. We are all a team. We are working as one } \\
\text { to achieve the same goal" (Contractor \#3- Project Manager) } \\
\text { "There were some issues with change of personnel. That always throws a project out" (Consultant \#10- } \\
\text { Client Representative) } \\
\text { "They were out of their comfort zone" (Consultant \#3- Architect) when forced to work in an environment } \\
\text { where a cooperative and team work approach was fostered } \\
\text { "You have an unsuccessful project generally when individuals do not get along (Consultant \#11- Project } \\
\text { manager/Quantity Surveyor) }\end{array}$ \\
\hline Trust and project outcomes & $\begin{array}{l}\text { "Every project you have to build a new team. It is all new players. It is all new relationships" (Client \#4- } \\
\text { Project Manager) }\end{array}$ \\
\hline $\begin{array}{l}\text { Trust and the temporary nature } \\
\text { of a project }\end{array}$ & $\begin{array}{l}\text { "Every new project, you have to build a new team. It is all new players. It is all new relationships" (Client } \\
\text { \#4- Project Manager) } \\
\text { "You are creating a new project in its own right. A new team, and a new set of relationships every time" } \\
\text { (Client \#4- Project Manager) } \\
\text { "It goes back to this short term project. There are new relationships. So you have got to start all over again" } \\
\text { (Client \#4- Project Manager) } \\
\text { "Because in a temporary thing you have got to do it fairly quickly and you will probably be friendly by the } \\
\text { end of the job" (Subcontractor \#2- Internal partitions and linings) } \\
\text { "We need to do it from the start. Be cooperative at the beginning" (Subcontractor \#2- Internal partitions } \\
\text { and linings) }\end{array}$ \\
\hline \multicolumn{2}{|l|}{ TRUST FAILURE } \\
\hline Trust breakdown & $\begin{array}{l}\text { "They test the water early on to see what sort of project manager they are dealing with" (Consultant \#1: } \\
\text { Project Manager) }\end{array}$ \\
\hline Trust repair & $\begin{array}{l}\text { "Good and constructive relationships" (Client \#1: Contracts manager) along with "open communication" } \\
\text { and "working together to solve problems" (Contractor \#2: Project Engineer) were considered to be } \\
\text { important when responding to negative events } \\
\text { "Try to keep resolutions of issues as informal as possible, without the need to resort to formalising things" } \\
\text { (Client \#1: Contracts Manager) } \\
\text { "It is more important to be out there on site physically talking to people. Sorting out problems in person" } \\
\text { (Subcontractor \#1- Electrical Services) }\end{array}$ \\
\hline
\end{tabular}

